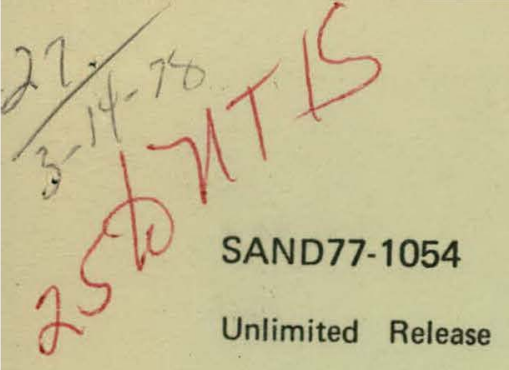

\title{
User/Programmer Guide for UCMD 84 Edit of a Macro for a Drawing on the Table
}

Donald K. Robbins

\section{Sandia Laboratories}

Printed February 1978

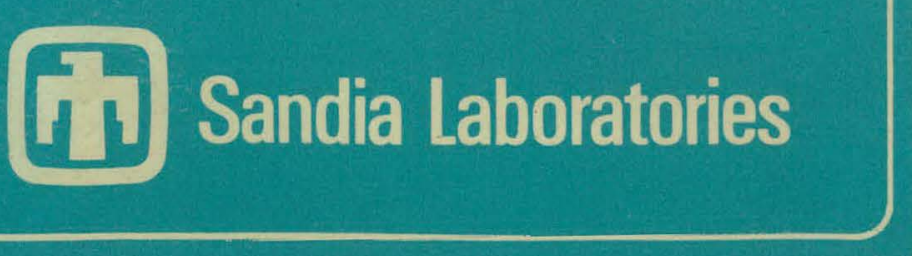




\section{DISCLAIMER}

This report was prepared as an account of work sponsored by an agency of the United States Government. Neither the United States Government nor any agency Thereof, nor any of their employees, makes any warranty, express or implied, or assumes any legal liability or responsibility for the accuracy, completeness, or usefulness of any information, apparatus, product, or process disclosed, or represents that its use would not infringe privately owned rights. Reference herein to any specific commercial product, process, or service by trade name, trademark, manufacturer, or otherwise does not necessarily constitute or imply its endorsement, recommendation, or favoring by the United States Government or any agency thereof. The views and opinions of authors expressed herein do not necessarily state or reflect those of the United States Government or any agency thereof. 


\section{DISCLAIMER}

Portions of this document may be illegible in electronic image products. Images are produced from the best available original document. 
Issued by Sandia Laboratorics, operated for the United States Department of Energy by Sandia Corporation.

\section{NOTICE}

This report was prepared as an account of work sponsored by the United States Government. Neither the United States nor the Department of Energy, nor any of their employees, nor any of their contractors, subcontractors, or their employees, makes any warranty, express or implied, or assumes any legal liability or responsibility for the accuracy, completeness or usefulness of any information, apparatus, product or process disclosed, or represents that its use would not infringe privately owned rights. 


\section{PAGES 1 to 2 WERE INTENTIONALLY LEFT BLANK}


SANII77-1054

Unlimited Rielease

Printed February 1978

\author{
(M) \\ User/Frogrammer Guide for UCMI $84=$ \\ Edit of a Macro for a Llrawing on the Table
}

-

Donald K. Fobbiris

Comfuter Aids System llevelofment Division 9624

Saridia Lahoratories

Albuaverave, NM. 87115

\begin{abstract}
This document describes frostam UCMD $84^{--}$an Afplicon AGS/870 User Command for editins a MACRO using the HP $2644 / 5$ and returning it to the drawing on the table.
\end{abstract}

Printed in the United States of America Available from

National Technical Iriformation Services

II. S. Mefartiment. of Commerce

5285 Fort Royal Road

Spririgfield, UA 22161

Price: Prinited Lopy $\$ 4.50$; Microfiche $\$ 3.00$

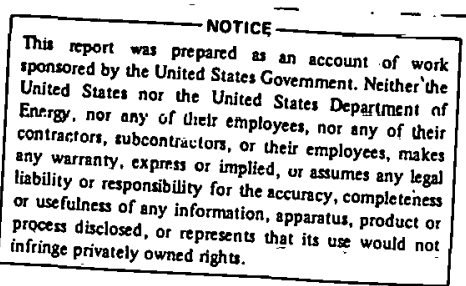

3-4

sponsored by the United Sted as an account of work

United States nor the Unis Govemment. Neither'the

conergy, nor any of thely employeen, nor anyent ne

any warranty contractors, or their employees, makes

of useful responsibility for the accuracy, completeness

process disclosed, or represents, apparatus, product or

infringe privately owned nights. 


\section{CONTENTS}

i.0 Iritroduction

\subsection{Execution In!structions}

2.1 Irifut

2.2 Outfut

2.3 Operatiris Frocedure

2.4 Error Messages

2.5 Examile

3.0 UCMI 84 Frosram liocumeritation

3.1 Ilocumentation Guideliries 11

3.2 liate of llociumeritatiori

3.3 Name of Frosram. 11

3.4 Name of Author of Frosrami 11

3.5. Name of Frosram Administrator. . 11

3.6 Ilate Prosram was Completed $\quad 11$

3.7 Brief Llescristion of Frasram 11

3.8 Full Narrative llescriftion of Frosram

3.8 .1 Gerieral 12

3.8.2 Iritialization 12

$3 \cdot 8 \cdot 2 \cdot 1$ I/0 Buffers 12

3.8 .3 Oftioris Arrays

3.8 .4 RUN1

3.8 .5 FOUNL 14

3.8 .6 STOF $\quad 15$

3.8 .7 END 15

3.8 .8 Subroutiries 15

3.8 .8 .1 Utilities 15

3.8 .8 .2 STR.CMII 16

$3.8 \cdot 8 \cdot 3$ IIECOLE.SECTOF 16

3.9 Hardware Confisuration Fiequired 17

3.10 Larisuase Used . 17

3.11 Oreratiris System Used $\quad 17$

3.12 Type of Prosram 17

3.13 SFecial Foutiries. Used 17

3.14 Form of Frosram . . 17

3.15 Prosram Flow Chart 18

$\begin{array}{ll}3.16 \text { Prosram Listiris } & 20 \\ 3.17 & 20\end{array}$

3.17. Backisf Cafability . 20

4.0 Record of Chariges to the Frosram 20

5.0 Key Words . . . . $\quad 20$

\begin{tabular}{lr}
6.0 & References \\
\hline
\end{tabular}

$\begin{array}{lr}7.0 \text { nistributior, } & 22\end{array}$ 


\subsection{Iritroduction}

MACROS are rormally edited for a drawirg (which is or the table) by kesiris in the conflete MACFo from the kesboard. UCMI. 84 allows a. MACKio to he disflased on the screen of the HF $2644 / 5$. The editiris cafability of the HF $2644 / 5$ is used arid ther the edited MACFO cari be added to the dictionary of the drawiris on the tahle.

2,0 Executiris Iristructioris

The Afolicor Grafhics System (AGS) frovides a dictioriary for a drawins. UCMI 84 frovides a mecharism for obtairins a a MACFio from a drawiris dictionary or the table arid for editiris that MACKO with the HF 2644/5. This MACKO is ther returried to the dictionary.

\subsection{Irifut}

$-m--$

UCMD 84 is executed from an AGS activity.

The MACFio ranie is infut from the kesboard. This MACkio will be found and disflased on the screen of the HP $2644 / 5$.

Three oftioris are available from the kesboard. The oftioris are:

$$
\begin{aligned}
& \text { a. 'I'escribe' } \\
& \text { b. 'T'able } \\
& \text { c. 'A'bort }
\end{aligned}
$$

This lists the optioris available.

This ruris the frosram. The MACFio reaisested will be fourid arid disflayed or the screer of the HF $2644 / 5$.

This aborts UCMD 84 and returris to the AGS ststem

\section{$2 \cdot 2$. Dutfut}

The execution messages produced by UCMII 84 start with the initial provifiris messase to allow the user to select the afprofriate oftion. All irifut is echoed back to verify what the computer sees. 


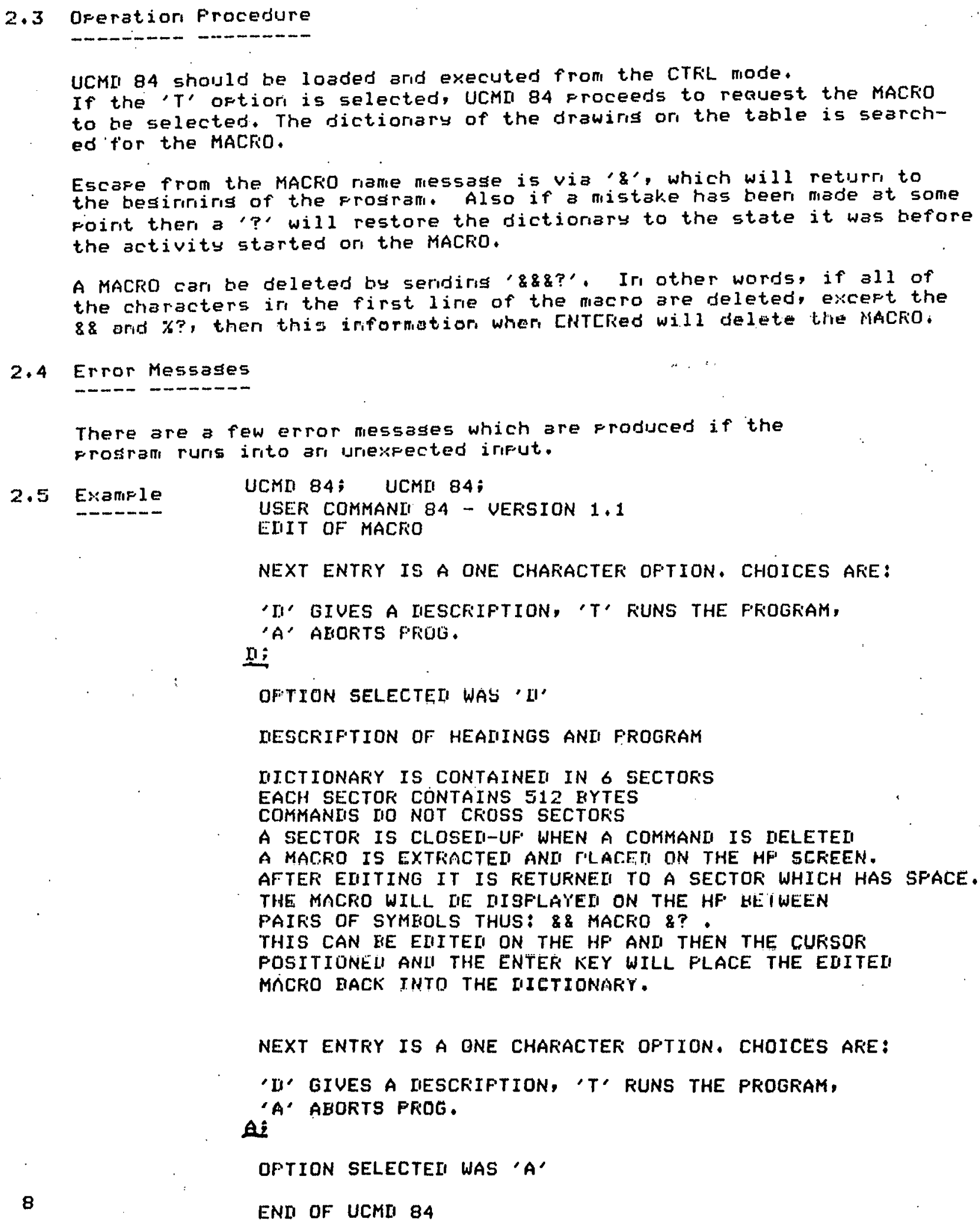




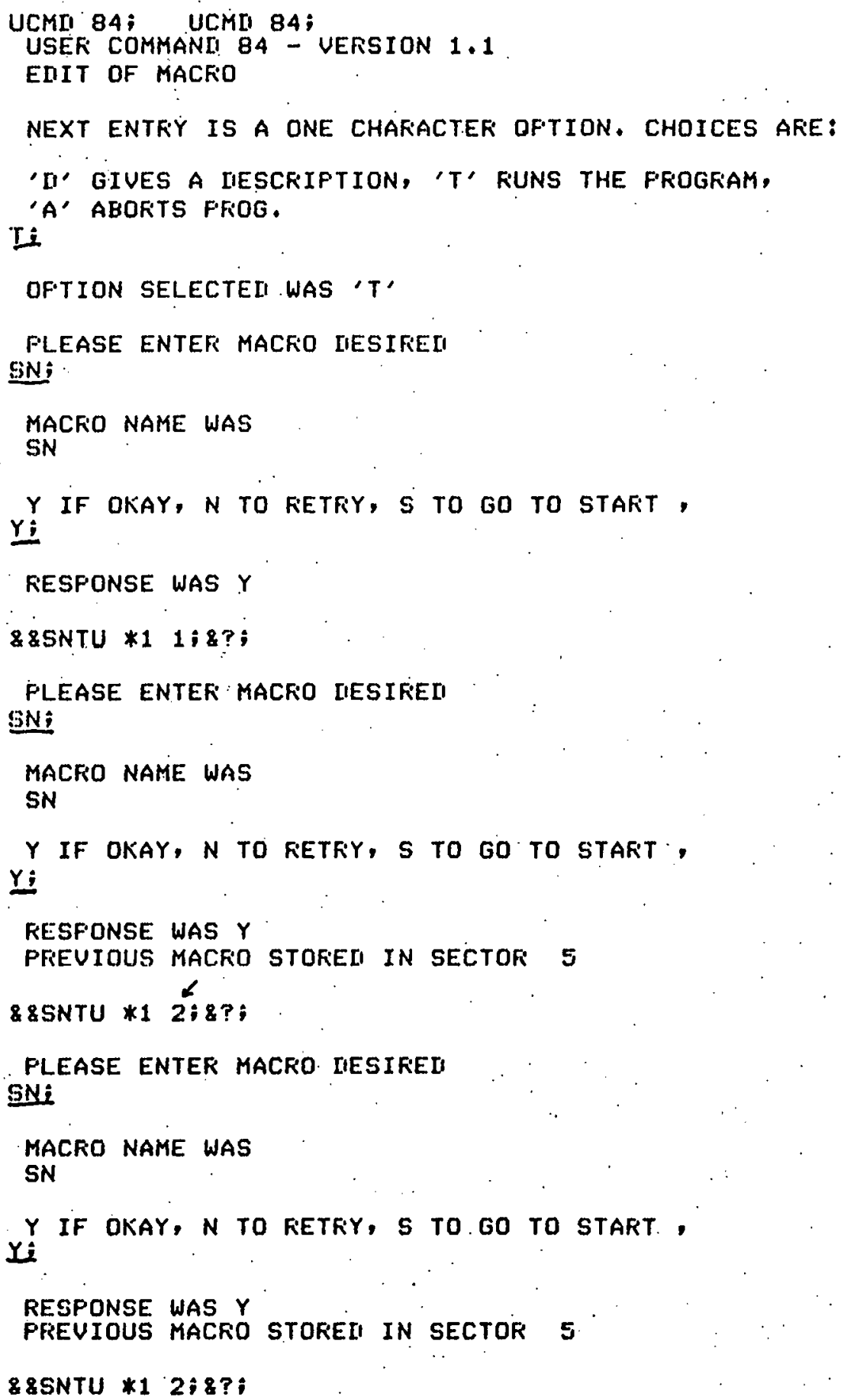




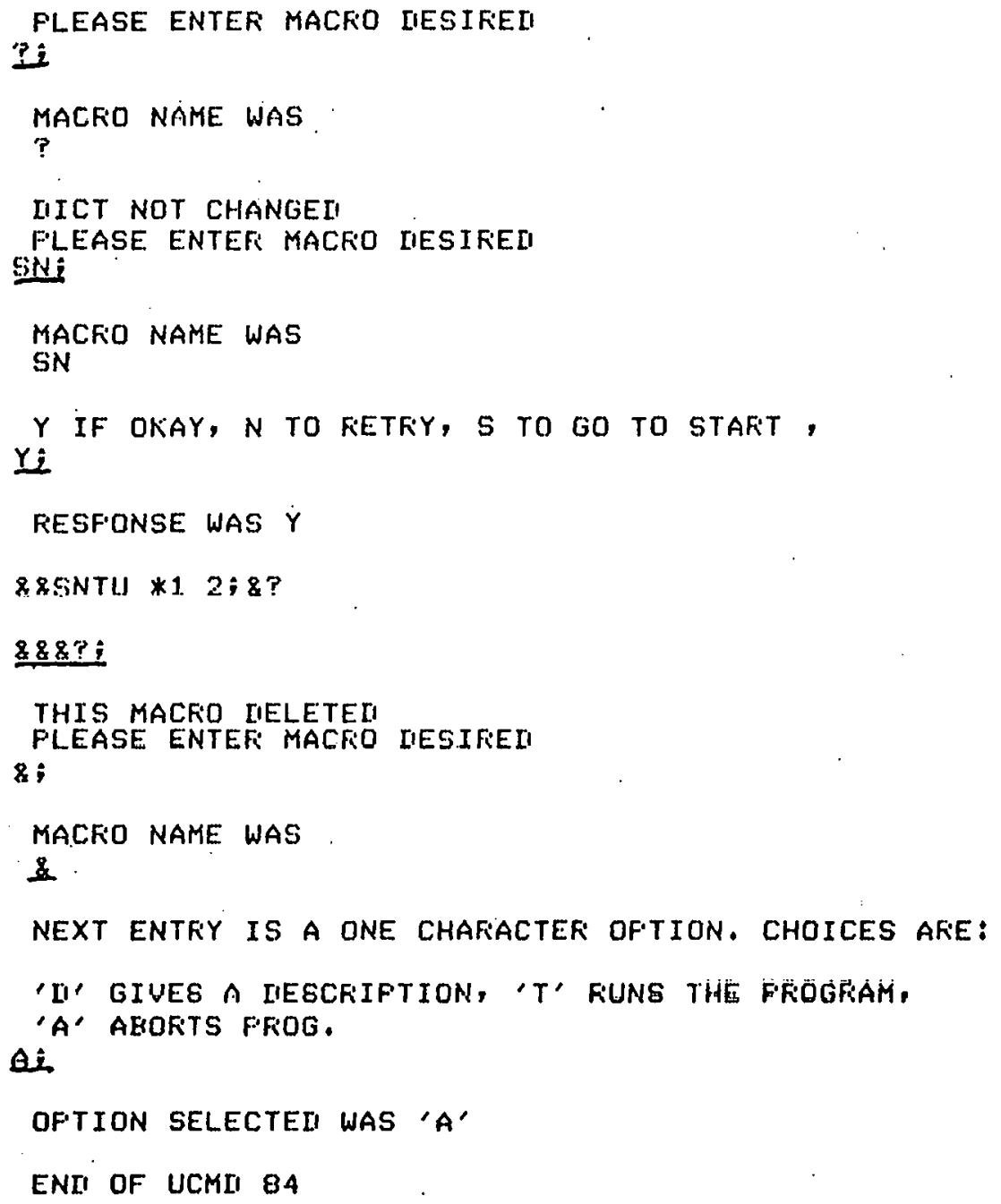




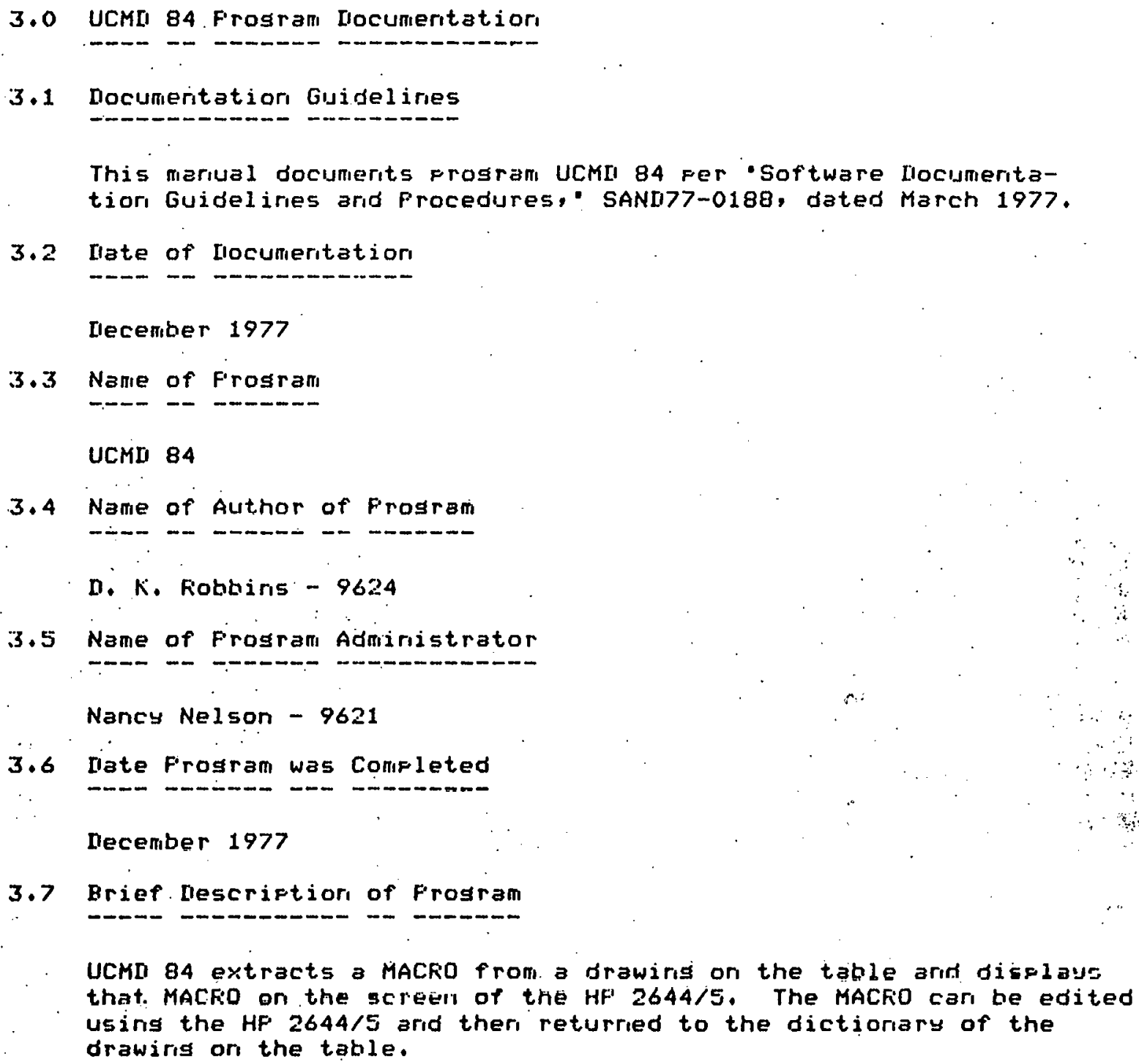


3.8 Full Narrative llescriftior of Frosram

3.8 .1 Gerieral

UCMI 84 is writter in the BCFL Frosrammins Languase.

The source code was developed on the HF $2644 / 5 A$ terminal.

This video iriteractive termirial fermits easy editiris of

existirig code. Accordirisly the frosram is hishly commerited.

riecolise of the rumbar of magsages in the frostam iwhich eabses

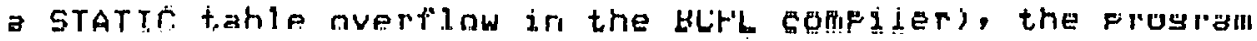

is sefarated irito three sesments. These are iridicated by a

sirisle feriod ori a line by itself. The slobal entities used

by each sesmerit must be deciared.

3.8.2 Initialization

Initialiatiation

The frosram starts with a commert block as to what is afoot.

This is followed by declaring the globals arid variables used.

The files AGSLIB.HIIF arid FILIIEF. HIIR are obtained with the GET

commarid. These two files coriain slabal declarations for the ECFL sIJffort liturary. Cells 1 thru 139 are accouriter for by

these slobals. The subrautiries used by UCMII 84 are setup

in cells 140 thris 156.

TIE STATIC stotemeritg reserwe locotiong for tho various variahlos

used in the prosran.

Vectors are set $1 \mathrm{H}$ for the variables which reed vectors.

These vectors fall irito two catesories:

a) I/0 buffere (k,owboard)

b) Arrays

\section{8 .2 .1 I 10 Euffer}

There are $5 \mathrm{~KB}$ bisffers, ANS, ANS1, arid YN arid YN1. Orie buffer (EUFF) is used for storing the dictionary sector read from the dise. 


\section{8 .2 .2 Arrays}

There are six arrass.

a) NAM. A orie dimerisiorial array coritairing ter celis for storiris the MACFio riame to be used for searchirig.

b) FEEE. A six word array for storiris the free sface ir each dictionary sector.

c) CMII. A 120 word array where the MACfio extracted is stored.

d) CMn1. A 120 word array where the edited MACFo is coristructed awaitiris re-eritry to the dictioriary.

e) Wfik1. A 80 word array where the first lire of the edited MACFio is eritereds.

f) WFik2. A 80 word array where the second 1 irie (if riegded) of the edited MACFO is entered.

\section{$3 \cdot 8 \cdot 3$ Oftions}

Next, the prosram writes out a messase to the user iberitifyiris itself (UCMU 84) arid also lists the differerit oftioris which are available.

The oftioris are: 'D'escribe, 'T'able, 'A'bort.

The first character of orie of the above is entered from the keytioard followed by a CCF. This is accepted by the routirie GETSTFING, facked.by FACKSTFING, and listed out to the user. The oftion selectcd then soes irilu a mult1-brarich switch coristruct (SWITCHON) of BCFL. If aris other character other thar orie of the above is tyfed, ther, the IIEFALLT CASE rejects it arid returris to 3.8 .3 for another try. 
a) D'escribe

This CASE calls out the subroutine IIESCFIf and

returns to $3.8,3$.

b) 'B'IJS

This CASE turns sw to 1. This results in much intermediate outfut which was used for debussiris. Control returris to $3.8,3$.

c) ' $T$ 'stile

This case trarisfers to 3.8 .4 .

(1) 'A'mort.

This case trarisfers coritrol to 3.8 .7 .

e) Ilefatult

Aris other character erids 1 f here. A messase is writteri to the iser arid coritrol returris to 3.8 .3 .

$3.8,4$ FUN1

Coritrol is transferred to this label if the 'T'able ortior is used. Throush some dialosue with the user, the MACko riame is obtained. Also the NAM array is cleared. The gix sectors of the dictionary are read arid the. free sface in each orie is storeo in the FFEE array. This information is used for re-insertion of the MACFO irito the oictionary. Next the dictionary is read

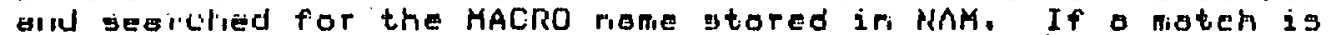
made, ther coritrol is transferred to 3.8 .5 . If riot, thori eoritrol soes to 3.8 .4 to look for ariother MACFO name. If the character ' 8 ' is entered as the resforise to the MACFO riame, then coritrol soes to 3.8.3. If '?' is criterco, ro charise is made in the dictioriary arid control soes to $3.8,4$.

3.8 .5 FOUNE

Control is trarisferred to here from 3.8 .4 if a MACFO riame match is fourid. The MACKO is extracted from the dictionary by the routirie AllJUST. This closes ur the sface in the sector. Also the FREE array is ufdated. The MACRO is writter out to the screen by WRITELN. Two lines. are uged if the MACRO waE more than 60 oharacters loris. The AGS system has a special use for the ' $"$ ' This is treated as a $\langle$ CFi〉. A MACFO can contain the '; symbol. There is a cell in the system which coritairis the ";". To be able to read that sumbol ('p') on iriest, the cell was charifed to 'Q'. After re-eritry of the edited MACFO the cell is chansed back. Citil. TEFiM is the routirie where this takes flace.

The one or two 1 iries of the MACRO are then edited or the HP $2644 / 5$. When thes are satisfactory, the cursor is fositioried at the lirie arid the eritiry kes ori the HF $2644 / 5$ is pushed. The MACKO is reconstituted in CMD1 and then control is transferred to 3.8 .6 . 
Here the MACFO iri CMLI is added to the sector with erioush free sface to accommodate it. STR.CMII is the routirie which reads the Frofer sector, adds the MACKO, arid writes the sector back to the disc for the drawiris which is or the table. Coritrol soes to 3.8 .4 so that another MACFí carı be selected if desired.

\section{8 .7 ENI}

This terminates UCMI 84, writes a messase out to that effect and returns to the AGS systen.

\section{8 .8 Subroutiries}

\section{8 .8 .1 Utilities}

a) GETSTRING. This routirie reads a character from the H.eyboard arid flaces it in an arras.

b) FFINTUSEFi. This routirie fririts the User's riame on the outfut device.

c) IIEEUG. This routirie tests the error cell, If zero it RETUFiNS. If not, it prints out the cell ir octal, as well as the messase.

d) MESCFIF. This routine consists only of messases which are fut out to the outfist device explairibis the oftions availatile.

e) UNFACK. This routirie urifacks two bytes fer word to an array with one byte fer word, right justified.

f) FACK. This routirie facks the byte array back. irito the word array.

s) FRINTBUFF. This routirie decodes a word buffer arid prints the butes iri octal.

h) COMFACT. This routirie comfresses the sface in a byte arras where a dictioriary eritry has heer removed.

i) NAME. This routirie extracts the MACFO name arid futs it in the NAM arras. Irifut is from the keshoard.

j) COMFAF2. This routirie comfares NAM with the MACFio riane read by IIECOLE, SECTOF.

k) ADJUST. This routire reads the frofer disc sector which contained the MACFO ariu culliacts that sector. The free starase cell is also ufdated.

1) DECOIIE.FFEE. Extracts free storase courit from each of $s i x$ sectors arid flaces it ir FFEE array.

ii) CMI. TEFM. This routine sets the escafe character to 'e' or 'f'.

i) CMD.FiTN. This routine takes the bytes from the ANS array arid puts them in the WRK arras when the ENTER kes is hit or, the HF.

o) WRITELN. This routirie writes the MACRO onto the HF. screen with characters to deriote the MACRO limits. 


\section{$3 \cdot 8 \cdot 8 \cdot 2 \quad \mathrm{STR}_{0} \cdot \mathrm{CMI}$}

Then

This routirie iriserts a dictioriary eritry at the erid of the $J$ th sector. First the J'th sector is read from the dise arod 256 words are urifacked. The MACRO contained in CMII is added in the free sface available at the end of the sector. The hookkeefiris eritries of the sector are urdated. Next the byte arras is facked and writter back to disc.

\section{$3.0,8.3$. LECOLE. SECTOR}

This routirie is the orie where the dictioriars is reas. The J'th sector is read from the sisc. Next the buffer is urifacked irito a 512 byte array.

Thare are three tures of eritries fermitted jn a dictiorary sector, These are: 1) Commarid Symbols, 2) MACFos, 3) Merius.

Each eritry has a two bute header. This header coritairis a code which tells which of the three tyfes the eritry is. The routirie brariches to orie of three fiaces to decode the bytes which follow accordiris to the proper patterio.

If the tyre is a MACKO, then the MACKO riame. in NAM is comfared

to the MACFO name by COMFAFi. If a match is fourid, the MACKO

is cofied to CML arid a return is made to the calling routirie.

If the MACFo doesri't match, ariother commarid is read. 


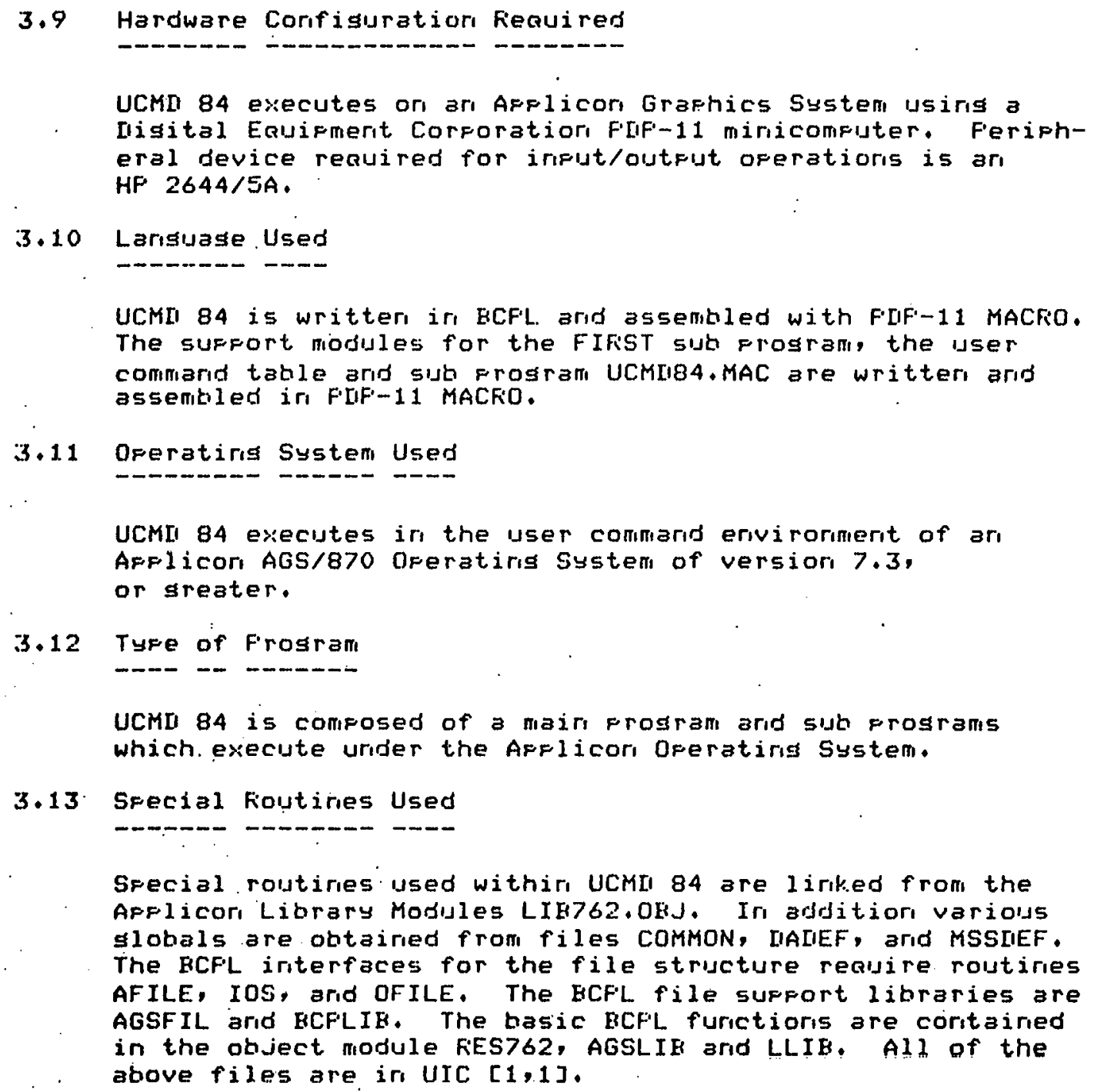

3.13. Srecial Foutines Used

Sfecial routiries used withir UCMII 84 are lirked from the AfFlicor Library Modules LIE762. OBJ. In additiori various slobals are obtairied from files COMMON, IIALEF, arid MSSIIEF. The BCFL iriterfaces for the file structure reauire routiries AFILE, IOS, arid OFILE. The ECFL file suffort libraries are AGSFIL arid ECFLIE. The basic BCFL furictioris are coritained in the object module FiES762, AGSLIE arid LLIB. Alt of the above files are iri UIC $[1,1]$.

3.14 Form of Frogram

-no- - - - - - - -

UCMI 84 is an absolute load module formatted for execution on the AGS System by the utility LDVALL.

Due to the riature of this user commarid it should be residerit on the system disc. 


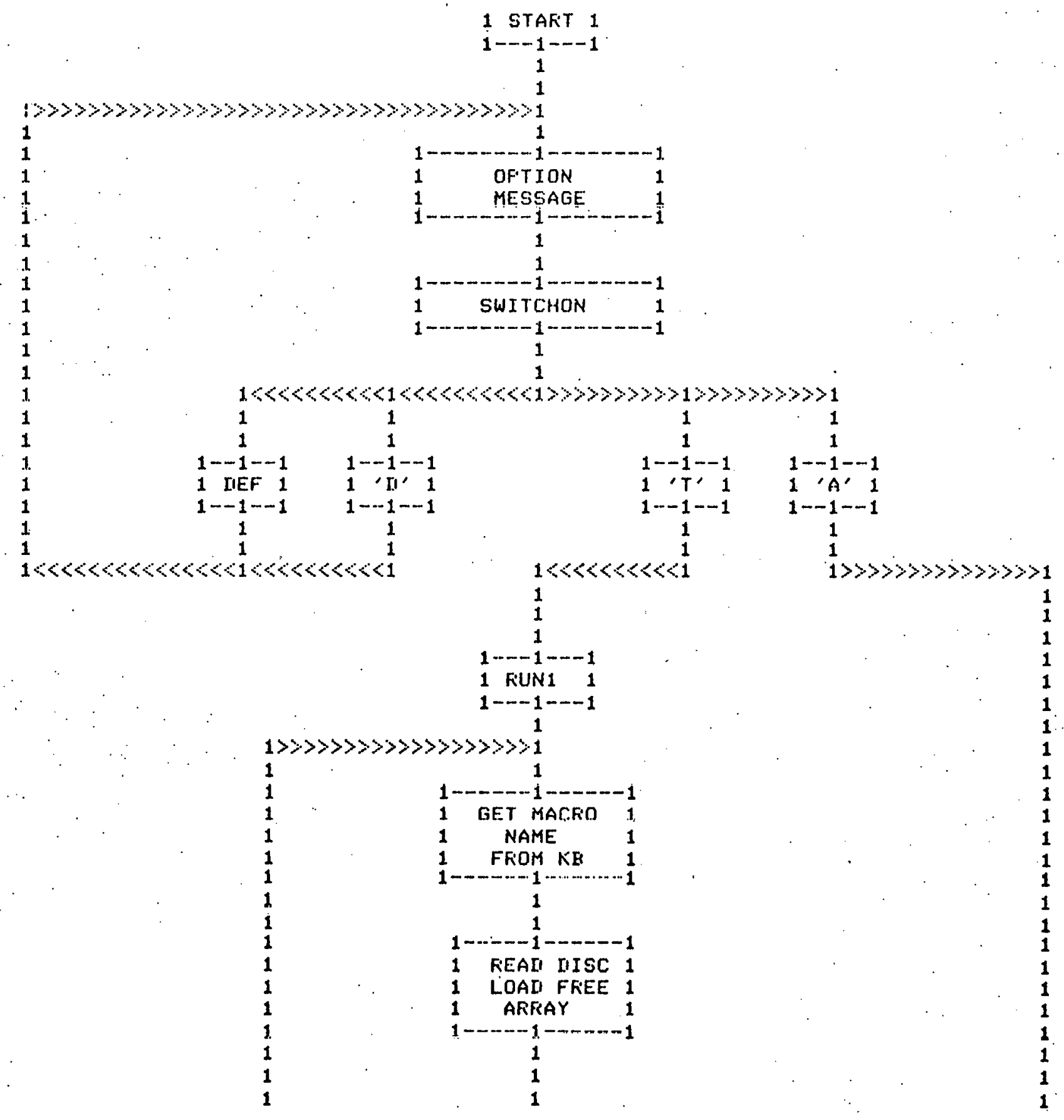




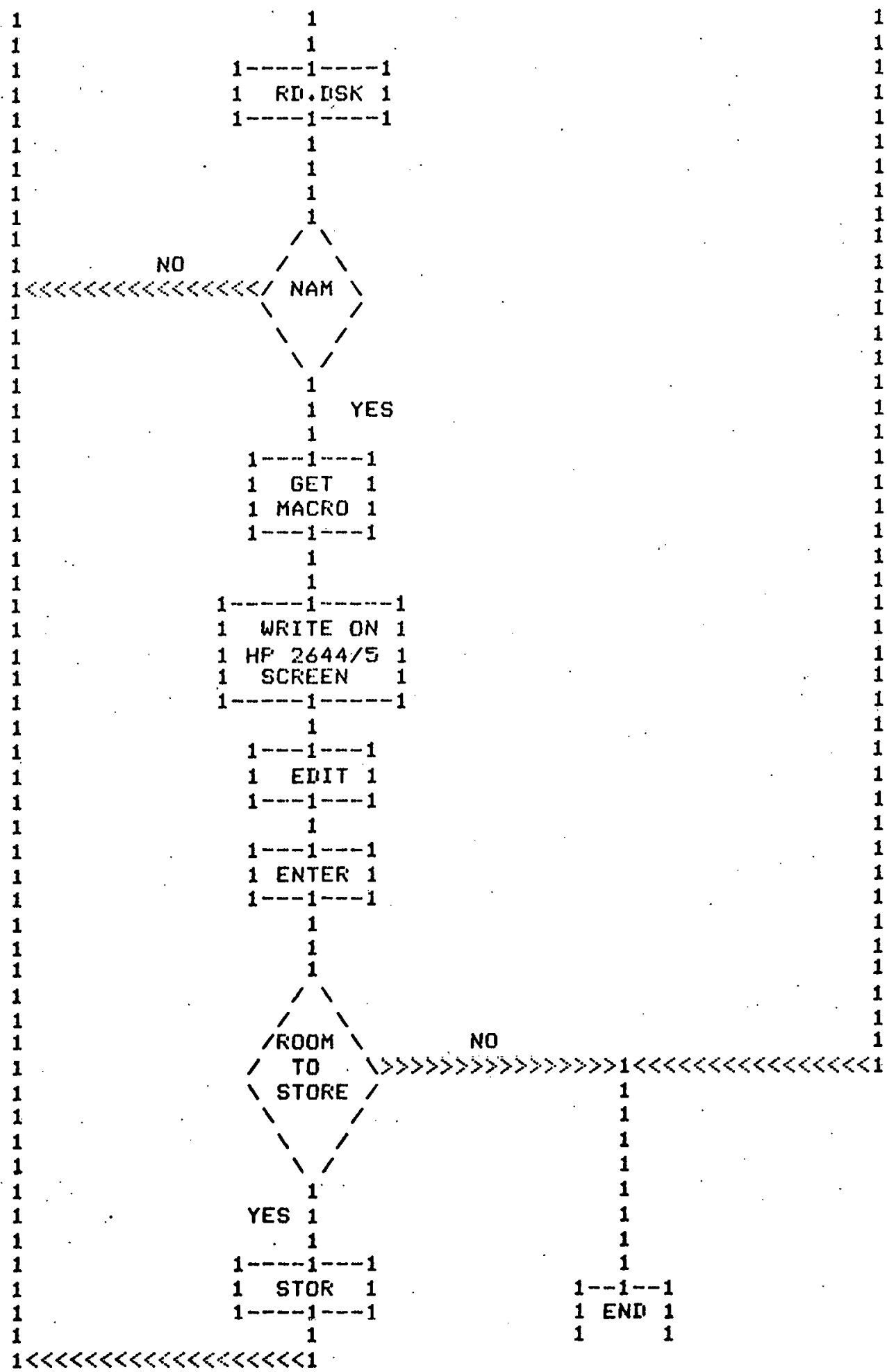


3.16 Frosram Listiris

A currert 1 istiris should be obtained from the 9624 Soft-: ware Coordiriator.

3.17 Hackinf Cafability

- - - - - - - - - - -

The followiris toS FIf directory shows $a 11$ of the files.

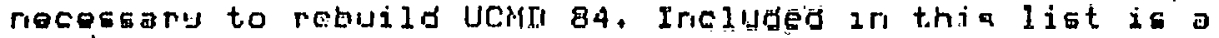
file named UCMLI84, BAT. This file coritains all of the nos/HATCH commariss to assemble, 1 irik. arid LOVALL the UCMn 84 prosiram. The currerit backup tare arid version should be obtairied from the software Certificate.

\section{IIIFECTORYY IIIO: $[300,16]$}

10-MAY -77

AGS184.MAC : $3 \quad 25-M A Y-7\rangle\langle 233\rangle$

EIITMAC, BFL IS 25-MAY-77 233$\rangle$

UCMII84. BAT 1 25-MAY-7> $\langle 233\rangle$

ULIMLI8.MAC 1. 25-MAY-77 233 .

UCHT84.MAC 1 25-MAY-7> 233$\rangle$

4.0 Record of Charises to the Prosram

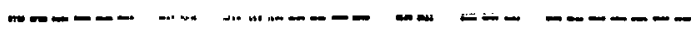

See Software Certificate

5.0 Key Words

-.- -....

Afflicor Graphic system, Edit Macro. 


\subsection{Fefererices

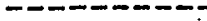

a. MACKio User Commanid Iriterface Oftion AGS/872 System

Fefererice Mariual, Version 3.000, Afflicori Incorforated,

Eurliristori, Massachissetts, February 1976.

b. IIOS/BATCH Harisbook, IIEC-11-OIEHA-A-D, nigital Equipmerit

Corforatior, Mayriard, Massachusetts, Afril 1974.

c. FIJ-11 Frocessor Hardbook, Ilisital Eauifmerit Corfora-

tior, Mayriard, Massachissetts, 1975.

d. Glaurier, T, R. MAIILS User Guide AGS/700, Saridia Laboratories, Drs. 9623 , Seftember 1976.

e. BCFL User's Mariual, J. M. Misdson, Ausiust 1, 1974. 


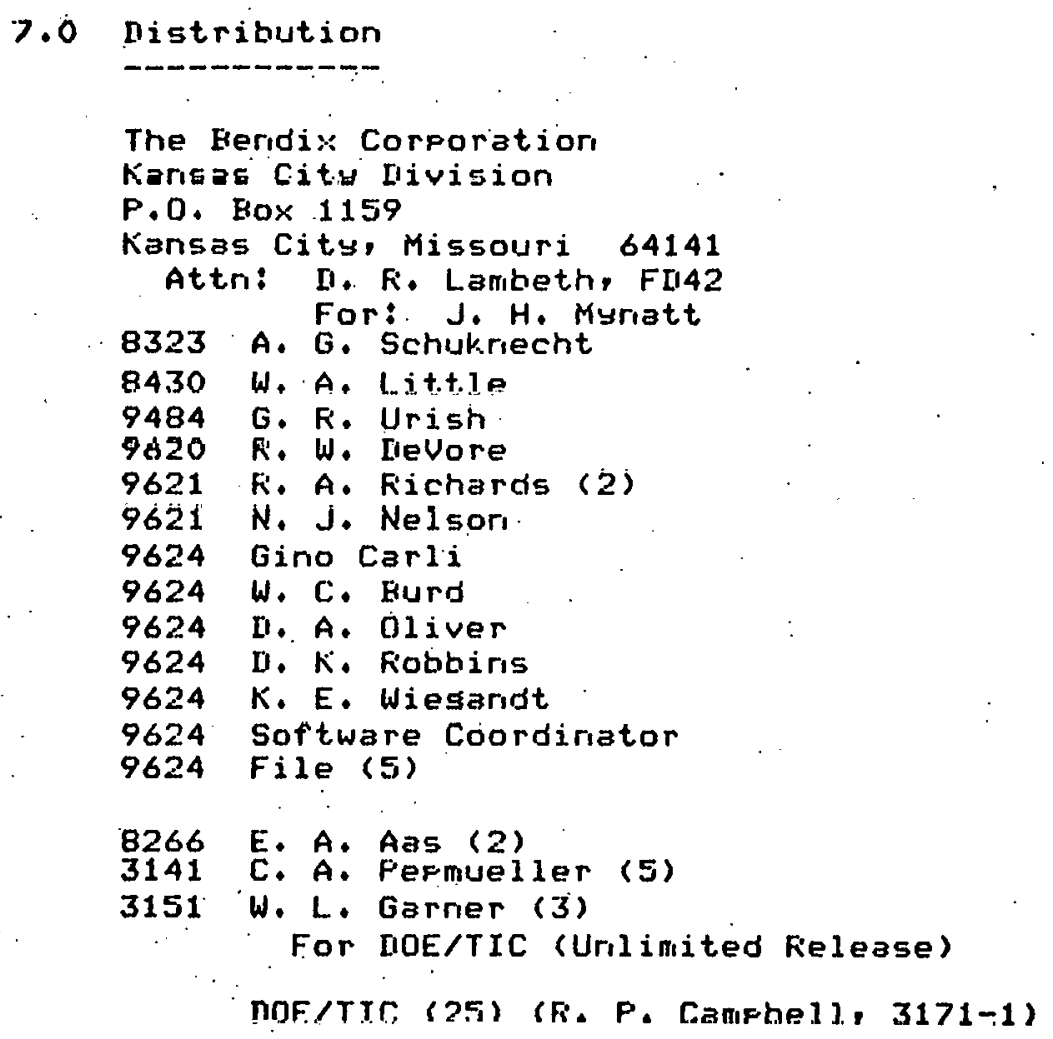

